\title{
No Governo dos M undos: Escravidão, Contextos Coloniais e Administração de Populações ${ }^{1}$
}

Cláudio C. Pinheiro²

Resumo

Como um dos mais poderosos da era moderna, o império colonial português estabeleceu colônias epossessões em vários continentes. Controlando vastas regiões, administrou ligações comerciais, de trânsito de mercadorias e pessoas entreestes pontos. Como conseqüência destequadro, foi obrigado também a lidar com diferentes grupos populacionais. $\mathrm{N}$ este processo, um vasto conhecimento foi gerado no sentido de se definir fórmulas de "governo" destas populações que foram, de uma forma ou outra, incorporadas ao império. Entre estes grupos populacionais estavam: "degredados", "gentios", "índios" etc; certamente um dos mais significativos (demográfica e simbolicamente) eram os "escravos". 0 presente trabal ho procura observar como muitos destes grupos foram sendo construídos como grupos, em diferentes contextos sócio-geográficos (em especial o Rio de J aneiro e G oa), a partir de práticas de administração de territórios e experiências sociais do "governo" de populações dentro dosquadros de políticas imperiais do exercício do poder. Assim, parte-se desta démarche para introduzir a perspectiva de como a idéia (moderna) de "escravo", paulatinamente construída pelo império colonial português, foi subsumindo e obscurecendo diferentes formas de vivenciar o cativeiro - ou seja, diferentes formas de trabalho compulsório - que eram encontradas em algumas colônias.

Palavras-chave: império colonial português, escravidão, globalização, produção da exclusão. 


\section{Abstract}

\section{On theWord's Govemment: Slavery, Colonial Context and Population's Administration}

Being one of the most powerful of the Modern Era, the Portuguese colonial empire has established colonies and possessions in several continents. Controlling large regions, it has administrated commercial connections, products' trades and people between these places. As a consequence, it had to deal with different population groups. D uring this process, a huge knowledge was achieved when trying to define government patterns for these populations, which were somehow added to the empire. Among these groups there were "exiled people", "heathens", "Indians" etc.; certainly one of the most important groups (demographic and symbolically) were the "slaves". This article observes how many of these groups were formed as graps in different social-geographic contexts (especially Rio de Janeiro and $\mathrm{Goa}$ ) because of the territorial administration and social experiences performed by these populations' "government" during the exercise of power according to the empyreal policy. This way, the author is starting from this démarcheto introduce the perspective of how the (modern) idea of slave, day-by-day built by the Portuguese colonial empire, darkened different ways of living in captivity - different ways of compulsory labor, which could be found in some colonies.

Keywords: Portuguese colonial empire, slavery, globalization, exclusion production.

\section{Résumé}

Au G ouvernement des M ondes: Esclavage, Contextes C oloniaux et $\mathrm{G}$ estion de Populations

Commel'impirecolonial portugai sétait l'un despluspuissants de l'Époque M oderne, il a installé des colonies et des possessions dans différents continents. C ontrôlant de vastes régions, il a gerédes liaisons commerciales, letrafic demarchandises et des personnes entre ces points du globe. Par conséquent, il a étéobligédeprendreégalement en compte différents groupes de population. Dans ce processus, une vaste expérience a été acquise dans la définition de formes de «gouvernement » de ces populations. Parmi ces «groupes», on trouvait: des «déportés», des «gentilhomes», des «indiens», etc.; I'un des plus significatifs (démographiquement et symboliquement) était celui des 
« esclaves ». C et article essaie de montrer comment beaucoup de ces groupes se sont constitués en tant que « groupes», dans divers contextes socio-géographiques (tout particulièrement à Rio de J aneiro et à G oa), à partir de pratiques de gestion de territoires et d'expériences sociales de «gouvernement » des populations. Ainsi, en partant de cette démarche, on peut introduire la perspective selon laquelle l'idée (moderne) d'esclave s'est constituée, au fin et à mesure, par l'impire colonial portugais et va subsumer, dépasser plusieurs formes de vivre l'esclavage, c'est-à-dire diffèrentes formes de travail forcé que l'on retrouvait dans certaines colonies.

Mots-clés: impire colonial portugais, esclavage, mondialisation, production del'exclusion. 
Como é largamente conhecido, o império português foi um maiores armadas do período e possuía colônias (e possessões) ao redor do mundo: América do Sul, África (Guiné, Angola, M oçambique etc.) eÁsia - China (M acau), Índia (G oa) e M al aca (entre outras possessões coloniais no Sudeste Asiático) e até no J apão.

Estes colonizadores desenvolveram rotas e iniciaram redes de comércio entre pontos distantes do mundo. D e fato, não eram apenas formas de comércio que estas colônias compartilharam, mas, sobretudo, a administração de bens e mercadorias dentro de uma perspectiva imperial. Espécies animais (especial mente pássaros), tipos defrutas, variedades deárvores etc., em um enormegradiente de espécies naturais, foram transpostas entre as colônias e entre estas e as metrópoles européias, em um ritmo bastante dinâmico, durante toda a Era M oderna (C rosby, 1986; G rove, 1996). Essas transferências modificaram os meio ambientes locais, ecossistemas, culinária, tanto quanto costumes, formas de trabalho, relacionamentos e hierarquias sociais (Russell-Wood, 1993). A combinação de todos estes elementos teria criado o que G ilberto Freyre (1940) chamou de "o mundo que o português criou".

Sendo tão amplo e possuindo colônias em tantos lugares, este império português teve de lidar com diferentes grupos populacionais. D esde o princípio da colonização brasileira, no século XVI, por exemplo, estes colonizadores lidaram com: populações indígenas nativas (submetidas a formas de trabal ho compulsório), degredados, escravos negros trazidos da África para trabal har nas plantações de cana-de-açúcar etc. Especialmente a experiência de administrar grupos sociais entre diferentes partes do mundo era muito usual. Escravidão e diferentes formas de trabal ho compulsório foram utilizadas (muitas vezes simultaneamente) na produção de riquezas neste império. Para que se tenha uma pequena idéia da significância deste fluxo populacional, o Brasil foi, no $N$ ovo $M$ undo, a região que recebeu o maior número de escravosa partir do tráfico Atlântico. De acordo com o estudo clássico de 
Phillip C urtin (1969), estima-seque perto de 15 milhões depessoas foram transferidas da África para as Américas, entre os séculos XV eXIX, dos quais 4 milhões foram para o Brasil.

Assim, estamoslidando aqui com um processo de desterritorialização de bens e especial mente pessoas (populações), expansão decontatos culturais efluxo de comércio, associadosà expansão da fé católica e de caracteres ibéricos de ci vilização. N este sentido, desde o século XV os portugueses ampliaram o tamanho deste(s) mundo(s) conectado(s) - para usar a expressão cunhada pelo historiador Sanjay Subrahmaniam (1997). M esmo a percepção do mundo - com relação às diversidades humanas, por exemplo mudou muito depois deles (Bouchon, 1999).

Para pensarmos esta problemática, partimos aqui numajornada, seguindo o expansionismo imperialista português, as colônias e possessões que este processo foi fazendo. N esta tarefa, escoIhemos duas local idades deste "mundo português" distintas e distantes, como pólos de uma reflexão comparativa econectada: ascidades do Rio de Janeiro e G oa, colônias que viveram períodoseritmos de ascensão e declínio diferenciados (das atividades econômicas e da importância estratégica), dentro do sistema colonial português. N ão obstante, e tal vez até por estas características, pólos interessantes de serem considerados relacionalmente, especialmentelevando-setambém em conta aspectosligados à vida urbana e gestão de populações na própria metrópole lisboeta.

0 olhar sobre este cenário será também balizado pela consideração de uma problemática que vem sendo bastante explorada pelas ciências sociais na última década - tanto do ponto de vista empírico, quanto das discussões analíticas - , propondo questões cruciais sobre a percepção ea ordenação da vida de grupos populacionais em diferentes pontos do globo: o chamado processo deglobalização. Estaremos aqui, portanto, especialmente interessados nas formas de governo de populações ligadas ao trabal ho escravo, servil ou outras formas de trabal ho compulsório (africanas negras ou não) diante da perspectiva de um império deamplitude global.

\section{Ao Sul do Equador}

A cidade do Rio de Janeiro é palco inicial desta jornada. ${ }^{3} 0$ projeto colonizador português no território que mais tarde seria chamado de Brasil começa oficialmente em princípios do século XVI. Ainda durante esse século, estes colonizadores empreendem 
uma ordenação administrativa do território, introduzindo a cultura da cana-de-açúcar como base econômica de um sistema de exploração e povoamento, baseando-se em model os deação colonial já experimentados, por exemplo, em São Tomé entre os séculos XV eXVI (Alencastro, 2000). A cultura do açúcar é primeiramente introduzida na região N ordeste, migrando também para o Sul da colônia nos séculos seguintes (F reyre, 1954). Embora a importação de escravos negros africanos para o Brasil - para a manutenção das atividades econômicas primordiais desta empresa colonizadora - fosse verificável desde o século XVI, a escravização deindígenas nativos foi também muito largamente utilizada ( $M$ onteiro, 1988), embora a historiografia brasilei ra pouco atente para esta dimensão.

Ainda no século XVI a cidade de Salvador passa a ser a sede administrativa da colônia, que é, desde logo, inscrita numa rede mundial (comercial, mas também de transferência de contingentespopulacionais, edehierarquias sociais) submetida à autoridade administrativa metropolitana portuguesa. C arl Boxer (1982) chega a estimar que ao fim da U nião I bérica, no século XVII , o Brasil já fosse, econômica e demograficamente, mais importante do que o Estado da Índia na estrutura do império português.

Ao longo dos séculos XVII eXVIII a cidade do Rio de Janeiro cresce sensivel menteem significância dentro da estrutura do ultramar português (Bical ho, 1997; Alencastro, 2000). Tal processo se deveu ao aumento da importância do Atlântico Sul (especialmentea relação entre Brasil eAngola), etambém à desco berta eexploração de ouro no Centro-Sul do Brasil. Ao longo dos séculos XVIII eXIX, o porto do Rio de Janeiro passa a se configurar também em uma referência no tráfico de escravos para as Américas. E m fins do século XVIII, já era o principal porto da colônia na comercialização de africanos escravos - e certamente um dos mais importantes no comércio em geral do ultramar português - , com um índice de comércio ilegal, porém regular, bastante significativo. Entre fins do século XVIII eas primeiras três décadas do XIX, foram registrados os maiores índices de entrada de africanos escravos pelo porto do Rio de Janeiro, testemunhando-se também a prosperidade dos grandes comerciantes locais dedicad os a esta empreitada (Fragoso, 1992). N este período, a cidade passa a abrigar a capital da colônia brasileira - transferida de Salvador (em 1763) - e vai assim se configurando progressivamente como um dos mais, se não o mais, importante porto do Atlântico Sul. 
O século XIX testemunha um crescimento ainda maior da cidade. Logo na primeira década (1808), chega ao Brasil, instalando-se na cidade, toda a C orte de D . João VI, vindo fugida de Lisboa em função da invasão daquela cidade pelas tropas napoleônicas. A vinda da Corte (e toda a estrutura burocrático-administrativa do império português) para o Rio de J aneiro não serefletiu apenas em um crescimento demográfico exacerbado - já que esta C orterepresentava cerca de 15 mil pessoas (entrenobres, a elite cortesã e seus criados, mas também toda espécie de funcionários da burocracia do Estado português) ${ }^{4}$ - , mas num total reordenamento da estrutura urbana esocial em todos os seusníveis. A instalação da C orte portuguesa, somada ao longo período de desenvolvimento econômico quea cidade (eseu porto) já experimentavam, fazem desta uma das maiores e mais importantes urbes do N ovo M undo (M alerba, 2000).

Com a instalação da Corte metropolitana, a cidade do R io deJ anei ro transforma-se de capital da colônia em capital de todo 0 império português, passando a sediar a mai oria de suas instituições administrativas (escolas de medicina e cirurgia, tribunaise demais instituiçõesjurídicas, órgãos depolícia, academiasmilitares, bibliotecas, a Imprensa Régia, academias de artes, museus etc.). Além disso, um variado gradiente detiposétnicos diferentes - incluindo indígenas de grupos nativos, europeus de várias nacionalidades (vindos como integrantes de missões diplomáticas, científicas ou artísticas), asiáticos (como chineses, vindos para instalar a cultura do chá), somados ao amplo e variado número de etnias africanas dos escravosnegros - passa a ser visível no cotidiano da vida urbana.

É preciso marcar quea vinda da C ortelusitana para o Rio de Janeiro, além de dinamizar a vida na cidade, já com uma certa pujança, sobretudo econômica, redefiniu uma série de elementos, costumes, ordens sociais etc. Em suma, difundiu novospadrões de civilização na colônia. É claro que muitos destes novos signos de civilização, etiquetas, símbolos de prestígio, restringi ram-se mormente ao ambiente dos salões da C orte (como o hábito de falar-se apenas o francês no tratamento entre os nobres). Contudo, esses novos costumes, guardados oslimites e especificidad es situacionais, circularam com alguma amplitude em outras esferas dessa sociedade, que foi semarcando pela concorrência deum enorme caleidoscópio de hierarquias que se cruzavam e se sobrepunham, reordenando posições dereinóisenacionais, brancosenegros, pobrese ricos, escravos e livres. 


\section{Vida U rbana e Vivências da Escravidão}

Se, por um lado, havia esta vivência urbana de pujança e grande variabilidade de signos deci vilização e urbanidade, por outro, esteera um império que se baseava no uso (intensivo e extensivo) da escravidão, especialmente negra africana. N este sentido, a cidade do Rio de Janeiro de meados do século XVIII eXIX (que contava com um número expressivo de africanos escravos entre seus habitantes) experimentou, tanto quanto outras cidades escravocratasno $\mathrm{N}$ ovo M undo (W ade, 1964), um tipo de escravidão urbana bastante distinta dos sistemas (clássicos) da plantation escravista latino-americana.

0 corre que virtual mente todos os serviços urbanos eram re alizados por escravos: os transportes da cidade (tanto de mercadorias, como de pessoas); construção de estradas; calçamento das ruas; edificação de prédios etc. Além disso, havia uma associação especial entre escravidão e a estrutura das resi dências. Como a cidade não dispunha de serviços de esgoto sanitário e de fornecimento de água encanada, cabia aos escravos da casa irem diariamente às fontes e chafarizes buscar água para a cozinha e a higiene dos moradores, bem como correr ao mar para despejar grandes barris de excrementos. $\mathrm{N}$ a mai oria dos casos, todas as demais necessidades diárias das resi dências - compras dos al imentos e outros gêneros, por exemplo - também eram realizadas pelos escravos.

A utilização dos escravos se dava tanto no serviço das necessidades pessoais do proprietário (em serviços nas residências, ou em oficinas, obras, indústrias etc), ${ }^{5}$ quanto trabal hando para terceiros, ou seja, outras pessoas que não seu proprietário. 0 corria, com bastante freqüência, que muitos dos escravos não eram utilizadospor seusproprietárioscomo força detrabalho - trabalhando em suaspróprias residências, oficinas ou negócios - , mas prestando serviços a terceiros, obtendo por isso uma remuneração (ou seja, como fontes de renda). Q uando se viam privados do rendimento proveniente do trabalho de seus escravos, muitos senhores acabavam em situação de penúria material, como era o caso dos diversos proprietáriosque an unciavam escravosfugidosnos periódicos, ou daqueles que enviavam pedidos às cadeias e prisões da cidade (através da Câmara M unicipal), para a soltura de seus únicos "meios de subsistência". 0 emprego de escravos em atividades que remunerassem seus proprietários parece ter acompanhado a estrutura de posse de cativos na cidade. A maior parte dos habitantes 
possuía pou cos escravos (de 1 a 3) e era nessa faixa que se registravam a maioria dos pedidos para "trazerem [os escravos trabal hando] ao ganho" (Pinheiro, 1998:82-102). ${ }^{6}$ Esta estrutura urbana de ordenamento social dos indivíduos fazia com que o recurso aos escravos fosse imprescindível, especialmente nas unidades residenciais familiares ("fogos"). N as três primeiras décadas do século XIX, estima-se que $90 \%$ doshabitantes da cidade possuísseao menos um escravo (Fragoso, 1992:76). D urante todo o século, M ary Karasch (1987:61) calcula que houvesse nos domicílios uma mé dia de moradoresque oscilava entre 6 e 10 pessoas, dos quais de 3 a 4 eram escravos - o que fazia com que aproximadamente 40 a $50 \%$ dos habitantes de resi dências da urbe fossem cativos. A posse de escravos fazia parte das exi gências da vida dos habitantes da cidade, já que se por um lado emprestava distinção e prestígio - 0 trabalho mecânico era visto de maneira pejorativa - , por outro, em muitos casos, garantia o sustento da casa. A concentração de escravos negros africanos era tamanha que vários cronistas que passaram pela cidade entre fins do século XVIII e o XIX, reportam 0 fato de se sentirem numa cidade africana. E m números absolutos, entre os anos de 1820-50 aproximadamente, a cidade do Rio de Janeiro representava a maior concentração urbana de escravos do mundo, desde o fim do Império Romano (Alencastro, 1997:24-5).

Estas circunstâncias combinadas fizeram surgir uma série de conhecimentos e práticas específicossobrea administração, controle e gestão desta população escrava negra que estava profundamente imbricada no cotidiano da vida dos habitantes da cidade do R io de aneiro eque, por isto mesmo, preocupava tanto as autoridades e os habitantes. $O$ Brasil da primeira metade do século XIX apresenta uma situação especial para observarmos como foram aos poucosse constituindo, ese complexificando, a racionalização dos saberes deadministração eo controle de populações (especialmente os "escravos"), migradas (compulsória ou voluntariamente), de todos os cantões do vasto I mpério ultramarino português (Pinheiro, 1998). Considerado de maneira mais ampla, esteéum período no qual grande parte dos empreen dimentos col oniai s eu ropeus no $\mathrm{N}$ ovo M undo acumulam um rol bastante significativo de conhecimentos sobre a utilização e o governo de negros africanos escravizados em suas colônias nas A méricas.

$\mathrm{N}$ o caso brasileiro percebe-se a intensificação de escritos, de natureza bastante variada, sobre as condições de vida dos escravos no Brasil, indo bem além desimples registros (eclesiásticos, jurídi- 
cos, policiais etc) da existência destes cativos. Estes textos, a despeito de serem elaborados com finalidades e para públicos leitores bastante diversos, tinham em comum a idéia de se conseguir um "melhoramento da sorte dos escravos no Brasil". Essa produção incluía desde ensai os jurídicos até textos econômicos sobre o comércio de escravos, memórias sobre a escravidão, projetos políticos proferidos na C âmara dos D eputados, códigos de posturas da Câmara M unicipal, teses médicas etc, que, associados a outros tipos de registros consultados - correspondência entreas autoridades policiais da cidade, anúncios de escravos nos periódicos urbanos (de compra, venda, aluguel efugas) e mesmo a literatura ficcional brasileira contemporânea - não apenas enunciavam a preocupação em se pensar formas de admi nistrar a população de escravos da cidade, mas as formas de agir em relação a estes. D aí, por exemplo, a quantidade de despesas e indivíduos (desde corposadministrativos constituídos pela polícia e pela Câmara M unicipal, até pessoas sem profissão definida, que viviam do expediente de capturar escravos fugidos) que se empregavam natarefa de controle e vigilância dos escravos da cidade.

Tanto estes escritos, como os demais registros da vida de senhores e escravos na cidade, não indicam tanto a produção de novos saberes sobre a escravidão brasileira, mas o recurso a conhecimentos já amplamente compartilhados (conhecidos e empregados) nesta sociedade escravocrata (herdeira de um legado lusitano de governo de populações). O u seja, muitos destes saberes não teriam sido desenvolvidos especificamente a partir do transporte de africanos escravizados para a América portuguesa, mas foram pensados para outras situações e contextos geográficos e sociais e eventual mente empregados aqui. Coisas deste império ultramarino que contava possessões em todos os continentes do globo, eque foi, em função disto, aos poucos produzindo conhecimentos sobre a administração das populações com as quais se relacionava, quer em paz, quer em guerra.

Entretanto, essa progressiva expansão e complexificação de saberes (conhecimentos, informações, modos de classificação) administrativos (práticas de vigilância, controle e punição) sobre 0 contingente escravo empregado no Rio de Janeiro do século XIX, se deu tanto em função das características do uso dos escravos no ambiente urbano carioca (como vimos acima), quanto pelo temor general izado da possi bilidade de ocorrência de grandes rebeli iõese insurreições escravas(K lein, 1987; R eis, 1987; G enovese, 1983). 
$M$ as não era apenas em função deste temor que se procuravam pensar em formas de melhor administrar esta massa de escravos, que constituía, no Brasil, parte considerável da população. $M$ uitos registros indicam, al guns até prescrevem, formas de convívio entre senhores e escravos que extrapolam o simples uso da violência física como elemento responsável pela manutenção da escravidão eda coerção doscativos ao trabal ho. Como dizia Perdigão M alheiro (1976), importante jurista brasileiro do século XIX, pensar em melhorias das condições de vida dos escravos não era apenas uma questão de "humanidade", mas de "reciprocidade", já que um escravo bem tratado serviria de "melhor vontade", tornar-se-ia "melhor", ecom isso lucraria não só o senhor, masa sociedade, poisse consegui ria não apenasa "paz nasfamílias, e portanto na ordem pública", mas "no resultado econômico em relação à produção". Possuíam, muitos destes textos, uma visão mais sistêmica, bastante ampla, do que poderia representar a melhoria nas condições de vida dos escravos: paz e lucro.

Recuperando uma D imensão G lobal na Lógica Local

À medida que refletia sobre as formas de governo (gestão e controle) da população escrava negra urbana no Rio deJ aneiro dos oitocentos - postas em prática pela administração deste novo Império brasileiro - , perguntava-me de onde teria vindo o conhecimento de como controlar eordenar esta população negra, sobretudo escrava, urbana? Certamente este conhecimento não se fez da noite para o dia. C omo teriam, então, operado estes mesmos saberes e práticas de controle e dominação escrava para o período anterior à proclamação da independência do Brasil de sua antiga M etrópole? Como operava esta lógica administrativa em outras possessões (que também faziam o uso de mão-de-obra escrava negra africana) do ultramar português? D e que maneira teria se dado a gênese, nos quadros da administração colonial portuguesa, de conhecimentos (códigos de leis, alvarás, posturas etc.) específicos para o controle de populações escravasnegras africanas nas suas diversas possessões ao redor do mundo? Teriam estes saberes sido desenvolvidos para outras populações autóctones de outras áreas submetidas à ordem colonial eposteriormenteaplicados a circunstâncias de uso de mão-de-obra escrava africana (sobejamente transladada entre as colônias)? 
U ma perspectiva interessante diante de tais questões é pensarmos como I mpérios coloniais no $\mathrm{N}$ ovo $\mathrm{M}$ undo, a partir de características semelhantes, geravam aparatos administrativos diferenciados para a escravidão negra. Se partirmos de aproximações, ainda que bastante superficiais, acerca de conhecimentos desenvolvidos para a gestão da escravidão negra: Iegislação, instituições administrativas de Estado etc., podemos notar o quanto estas eram visíveis em várias das colônias escravistas das demais metrópoles européias no Novo Mundo, e menos visíveis para o caso luso-brasileiro. N ão que não houvesse, no caso português, leis (alvarás, posturas etc.) específicas para o controle da população escrava das colônias. H avia.' M as não centralizadas na forma de um códi go como havia no caso das demais M etrópoles escravistas européias para a escravidão negra. A exemplo das possessões espanholas com seu "C ódigo N egro" - destinado exatamente à tarefa de regular a vida desta população - , em muitas das colônias escravistas americanas (francesas e holandesas, por exemplo) havia uma legislação específica para o tratamento e administração da vida escrava (Sala M olins, 1992). A inexistência de um código negro para o mundo lusófono certamente não era característica, como al guns historiadoresbrasileirosjá fizeram crer, da absoluta desorganização ecaos das estruturas legislativa eadministrativa do I mpério português. Basta tomarmos comparativamente a circunstância da administração de populações indígenas nativas, com as de negros africanos. É curioso perceber como na situação do "governo dosíndios" este mesmo I mpério foi capaz de gerar um código legislativo específico preocupado com a administração de uma população específica (Almeida, 1997), diferente do que ocorrera (não ocorrera) para populações escravas e negras.

N o que se refere a uma produção escrita de conhecimentos luso-brasileiros sobre a administração da escravidão, verifica-se uma grande concentração destes no século XIX, o que já marca uma importante diferença em relação às demaispotências européias que possuíram colônias nas A méricas. N o caso daFrança, as primeiras tentativas de sistematizar um conjunto de normas que regulassem a vida dos escravos negros em suas possessões foram estabelecidas ainda no século XVII, com o Code N oir (Código N egro de 1685), inicialmente destinado às colônias das Antilhas e do 0 ceano Índico (posteriormente - em 1724 - estendido à Louisiana). A este código seguiram-se diversas outras publicações oficiais do governo francês, destinadas à administração dos escravos das colônias. A exemplo de França, Espanha e H olanda (esta últi- 
ma em 1784, mormente destinada à G uiana), produziram legislações semelhantes para suas colônias escravocratas (cf. Perdigão M alheiro, 1976; Sala M olins, 1992). Entretanto, resgatando a dimensão de que o Brasil, enquanto colônia e mesmo como ex-colônia, integrava uma estrutura mais ampla - a do ultramar português - , vemos que os conhecimentos dirigidos ao controle da população escrava brasileira estava inscrita nesta estrutura. Estes conhecimentose práticas abrangiam, no âmbito do ultramar português, desdetécnicas de construção naval, rotas decomércio e correntes marítimas, cartografias da costa africana, com referências aos portos de obtenção de negros escravizados, relacionamentos diplomáticos ebélicoscom diversos reinosafricanos, atéformas de classificar - imputando-Ihes novas identidades - e de administrar estes enormes contingentes humanos, adequando-os às novas situações sociais que enfrentariam no N ovo M undo (Zurara, 1994; M attos, 2001; Lara, 2002).

D esta forma, um fator euma possibilidade que se configuraram como primordiais é a de tentar, a partir das especificidades pensadas e postas em prática no controle da escravidão negra urbana no Rio de Janeiro, recuperar esta dimensão - absolutamente gl obalizada eglobalizante - da administração de populações cativas no âmbito do império ultramarino português.

Esta operação de restituir a importância da lógica imperial portuguesa no estudo do Brasil (enquanto colônia de Portugal e/ou já como I mpério brasileiro), considerando-o enquanto parte deum sistema muito mais amplo é, historicamente, mal dimensionada por parte do meio acadêmico brasileiro. ${ }^{8}$ É importante recolocar esta dimensão na medida em que não apenas enquanto colônias, mas posteriormente, como ex-colônias independentes, estes sítios herdam um legado jurídico, administrativo e institucional das M etrópoles. Também J ohn Elliot (1987:4) e Anthony Pagden (1987), chamam a atenção para o fato de que a perspectiva da relação colônia-metrópole éindispensável para se conhecer colôniase metrópoles (tanto quanto as ex-metrópoles eas ex-colônias em seu fluxo interativo demudanças). A final, esta éuma relação constituída pela dimensão dialética e absolutamente dinâmica. Em maior ou menor grau, e por diferentes vias, todas estas possessões que compunham o ultramar português estavam integradas. C omo salienta LuisFelipeA lencastro (2000), não podemos compreender 0 Brasil (ea história deformação desteterritório) sem compreendermos a H istória do Atlântico. ${ }^{9}$ 
"G oa D ourada"

D o outro lado do globo, outro pólo de nosso interesse, a estruturação da parte oriental deste vasto império ultramarino português - em M acau, M alaca, C eilão e principalmente em $\mathrm{G}$ oa também se viabilizou em função do intenso intercâmbio comercial e defornecimento deescravos vindosa partir daÁfrica, especialmente de M oçambique (Russel-W ood, 1993; Pinto, 1992).

C ertamente, dentro da dimensão de um império que contava com possessões em pontos tão distantes do mundo, o papel da escravidão (e por extensão do tráfico de escravos) foi primordial. Trata-se, como chama atenção J eanette Pinto (1992:20), de uma das maiores experiências intercontinentais de investimento de capital da era moderna. Tanto quanto o Atlântico, o 0 ceano Índico foi de suma importância dentro da lógica administrativa e de consolidação da presença portuguesa no 0 riente. Se, para al guns autores, como C. Boxer (1982:18), a parte oriental do império português perde importância, desde meados do século XVII, em relação à Á frica e ao Brasil dentro da estrutura econômica do ultramar - desgastada que foi pelas su cessivas disputas bélicas com os holandeses por vários sítios - pelo viés da economia política e do exercício do poder, o Estado da Índia continua a ser peça-chave até, ao menos, meados do século XVIII (Russel-W ood, 1993).

D esde M oçambique, e especialmente nos séculos XVI e XVII (diminuindo mais sensivel mente a partir do XVIII), estabeleceu-se um intenso tráfico de escravos negros africanos com regiões das "conquistas" do ultramar português, especialmente $\mathrm{G}$ oa, M acau, C eilão e M alaca. Contudo, o comércio português de escravos no 0 riente, não se resumia às suas colônias, conquistas e possessões. A partir de $\mathrm{G}$ oa (especialmente), e passando por $\mathrm{M}$ acau, redistribuía-se até às Filipinas, sendo levados também para a Pérsia, Arábia, M ecca e Cairo. Este fluxo (humano e comercial) com a África incluía muito dos produtos das colônias portuguesas orientais.

A cidade de G oa já era um importante entreposto comercial no contexto asiático, desdeantes da presença portuguesa. A região foi palco de inúmeras disputas imperialistas envolvendo a expansão do islã na Ásia (Bouchon, 1999:23-94). D urante o século XV, integrou "rota das especiarias", da qual participavam portos e outros entrepostos comerciais na Ásia, G olfo Pérsico, M ar Vermelho e E uropa mediterrânea. G rande parte dos comerciantes da cidade eram imigrantes que circulavam entre pontos desta rota, constitu- 
indo comunidades (até princípios do século XVI), em sua mai oria islamizadas. Era uma cidademarcada pel o cosmopoliti smo. N o curto período do final do século XV e princípios do XVI conheceu: a velha cidade hindu (vassala do rajá de Vijayanagar - posteriormente destruída pelos muçulmanos); a cidade muçulmana, a partir da entrada (1475) dos sultões de Bijapur; e o domínio português (desde 1510). C ada um destes períodos presenciou a introdução de um aparato diferenciado de administração e novo ordenamento da vida social e religiosa (aspectos indistinguíveis). $\mathrm{N}$ a fase do domínio lusitano a cidade foi caracterizada então pel o convívio destas diferentes populações (hindus, muçulmanas, cristãs ocidentais etc.) num sistema social complexo que passa, por sua vez, a integrar esta estrutura colonial global dos portugueses. Segundo Geneviève Bouchon (1999), a partir da colonização portuguesa testemunhou-se a primeira vez que ocorreram transformações em grupos sociais asiáticos pela presença européia.

Goa tornou-se um dos maiores portos do 0 riente entre os séculos XVI eXVII, além de um local de enorme variedade humana e pujança urbana, chegando a ser conhecida pelos adjetivos de "Goa D ourada" ou "Lisboa do O riente". Capital do poderoso E stado da Í ndia, sediava a estrutura administrativa portuguesa que controlava possessões desde o $\mathrm{C}$ abo da B oa Esperança até os entrepostos comerciaislusitanos no J apão. Assim se configura nesteperíodo num dos maiores pólos de circulação e dispersão de pessoas do 0 riente - entre eles: membros do staff administrativo metropolitano (diplomatas, militares, governadores, autoridades eclesiásticas etc.), comerciantes (como os M hamais, que operavam dentro deste comércio escravista envolvendo o 0 riente português e a África oriental levando etrazendo escravos), e negros africanos escravizados. Todas estas características conferiram a G oa, a exemplo de outras cidades coloniais portuguesas, uma estrutura urbana bastante rica, tanto do ponto de vista comercial (da circulação de produtos de diversas localidades deste "oriente" e da Europa, África e N ovo M undo), como social (dado o intenso trânsito humano).

Segundo J eanette Pinto, a escravidão urbana em G oa, especialmente entre os séculos XVI e princípios do XVIII (a partir de quando esta colônia entra em decadência econômica acentuada) marcou-se pela combinação de aspectos: a) locais relacionados à propriedade escrava - ou seja, características regionais da escravidão (e outras formas de dominação: servos, criados etc.) que antecedem a presença portuguesa; b) característicos da base cultural 
portuguesa - como o desprestígio social pelo trabal ho braçal $;{ }^{10} \mathrm{c}$ ) da difusão generalizada da propriedade escrava entre os portugueses que ali habitavam; d) e mesmo das características particulares das formas de utilização dos escravos no ambiente urbano.

0 corre que a escravidão de negros africanos introduzidos pel os colonizadores portugueses não foi a única vivenciada na região. M esmo antes da chegada dos portugueses, diferentes formas de "escravidão" eram reconhecidas e praticadas, característica que continuou a subsistir no período da dominação portuguesa. M esmo o tráfico de escravos já era praticado na região desde longa data por muçulmanos, envolven do a troca e comércio de vários produtos asiáticos (Pinto, 1992:34-35).

Com a colonização portuguesa, o intenso convívio de populações diferenciadas (muçulmanas, hindus, cristãs etc.) não se refletia apenas no aspecto religioso, mas também em outras dimensões da vida social, como nas variadas formas de "escravidão" (seria melhor dizer de exercício do poder ou das práticas de cativeiro, como veremos abaixo) observadas neste contexto. Esta era uma sociedade com um interessante grau de plasticidade no estabelecimento de espaços de convívio de diferentes formas de trabalho e relações sociais. M esmo no âmbito do império colonial português, G oa parece ter representad o uma experiência bastante singular em relação a M arrocos, São J orge de M ina ou M alabar, já que no caso da Índia estavam lidando, os portugueses, com o confronto entre grupos sociais compl exos e dotados de sistemas de crenças e de ordenamento sociais bastantericos. A estrutura social hindu baseada no sistema de castas também foi, em al gum grau, incorporada à lógica administrativa portuguesa, tanto nas ações de conversão ao cristianismo, ou no que diz respeito à escravidão.

0 aspecto da conversão ao catolicismo também permeou bastante a idéia de catividade. Especialmente ainda durante 0 século XVI as conversões de nativos ao cristianismo acabavam pressupondo a redução destes ao cativeiro, como indicam as correspondências entre o vice-rei (Sebastião Pires) e o rei de Portugal, advertindo que tão logo batizados os nativos, passariam a ser tratados como cativos. ${ }^{11}$ Também com o intuito de garantir a propagação dafécristã, alvarás dos vice reis portugueses naĺ ndia proibiam a venda de escravos convertidos a não cristãos (procurando, com isso, coibir a reconversão destes a outras religiões). N a G oa pré-colonial portuguesa, tanto entre hindus quanto entre muçulmanoso uso da escravidão ("doméstica", assim como "agrária") era corrente. J eanette Pinto sugere mesmo que no caso da escravidão 
em G oa, os portugueses foram fortemente influenciados por um si stema escravista árabe: "aquele do patriarcal ismo personalizado e das rel ações familiares entre senhores e escravos, mais do que imitando o formato impessoal do sistema de escravidão industrial ou pré-industrial" (ibidem:19).

Especial mente no que tange ao uso urbano dos escravos, sua presença aparece discriminada em várias atividades da vida diária. Em G oa o trabal ho escravo era inten sa e extensamente utilizado tanto, por exemplo, no transporte (deágua para as resi dências, dos proprietários em seus palinquins, além dos objetos pessoais destes), como cozinhei ras que produziam iguarias para serem negociadas por vendedores (escravos) ambulantes nas ruas. Em muitos casos a utilização de escravos no trabal ho ambulante sustentava a residência de seus proprietários (ibidem:52). M esmo entre a nobreza local também era comum esta circunstância de os rendimentos das famílias e o sustento das resi dências ficar a cargo do trabaIho remunerado realizado por seus escravos para "empregadores temporários" - ou seja, para empregadores que não fossem seus proprietários.

Além destes aspectos, alguns autores (ibidem:24; Saunders, 1994:100-1) reforçam a idéia de que os colonizadores portugueses possuíam um grande desprestígio pelo trabal ho braçal (ou manual), o que requeria uma gran de quantidade de trabal hadores escravos e servos africanos, hindus ou estrangeiros. R azão pel a qual não apenas a propriedade de escravos parecia ser largamente disseminada, como também sua alta quantidade. ${ }^{12}$

Em grandemedida, tanto quanto em outros contextosescravistas modernos (em especial os do $\mathrm{N}$ ovo $\mathrm{M}$ undo), os escravos também operavam enquanto símbolos de status social e indicativos da riqueza de seus proprietários. ${ }^{13}$ Estima-se que perto de um quarto dos habitantes de G oa em meados do século XVII era composto de escravos, o queindica uma propriedade bastante disseminada desses entrea população, aspecto quenão se restringia aoscoIonizadores. Alguns registros indicam a existência de "nativos" (hindus e muçulmanos) possuindo escravos entre negros africanos.

0 emprego generalizado de escravos no ambiente urbano goêstambém implicou a necessi dade de se desenvolverem aparatos administrativos, ou minimamente preocupações definidas da Corte portuguesa com esta dinâmica do controlepopulacional em G oa. Tanto assim, que se verifica, desdefins do século XV III a produção de mapas de controle (e classificação) populacional, con- 
tendo distribuições sexuais, etárias e profissionais etc., com campos específicos para escravos, negros e livres.

O s portugueses, como ressalta Pinto (1992), gozavam de uma reputação de escravistas eficientes entre os E stados colonialistas rivais. Estavam especialmente preocupados com a boa gestão da população escrava - com o bom governo do cativeiro (Lara, 2003:210) - , visível tanto no controle das ações de casti go e punições infligidas pel os prop rietários aos escravos, ${ }^{14}$ quanto na preocupação com a segurança da sociedade pela circulação de grupos de escravos (e ex-escravos) pelas ruas e arredores da cidade.

\section{Produzindo G lobalidades}

Embora a dinâmica colonial do Estado da Índia e do Brasil estivessem dentro de ritmos bastante distintos em relação ao ápice do desenvolvimento econômico ou a pujança da vida social, ambos se aproximam em diversos aspectos. Estando sob o governo deste império ultramarino, estiveram sujeitos a dinâmicas e projetosadministrativos semel hantes (na ocupação dosterritórios coloniais, de instituição de atividades economicamenteprodutivas, de circulação de administradores coloniais e de escravos). Se tomarmosa estrutura da vida urbana em G oa eno Rio deJ aneiro, quanto à rel ação entreformas de habitar ediferentes maneiras de emprego da população escrava, é possível estabelecermos vários pontos de aproximação.

0 correque estas características da escravidão urbana não foram exclusivas de G oa e do Rio de J aneiro dentro do contexto do ultramar português. A. Saunders, observando as circunstâncias do cativei ro em Portugal continental entre os séculos XV eXVI, assinala diversos aspectos que, sendo socialmente construídos neste período, acabam influenciando fortemente as formas de cativeiro (escravidão, servidão etrabal ho compulsório) vivenciadas durante toda a época moderna atéo século XIX. Segundo Saunders esteperíodo exigiu procedimentos para conformar osnegrosafricanosescravos "a uma sociedade que conhecera sobretudo os mouros e uns tantos escravos canarinos, no decorrer da idade média" (1994:11, ênfase minha), a partir do crescimento do número de escravos elibertos em Portugal. Q uando da chegada dos negros em Portugal no século XV, a partir do contato mais intenso com a África, já havia um lugar social para os escravos neste contexto. O s séculos XV eXVI testemunham um refinamento das leis sobre os escravos, já 
que coincidem com um duplo movimento: primeiro no esforço pela codificação das leis portuguesas, e segundo com a entrada em massa de negros do ocidente africano. Em 1550 por exemplo, os negrosjá haviam substituído aos mouros enquanto o principal grupo étnico entre os escravos, chegando a representar até $10 \%$ da população de Lisboa e al gumas das principais cidades, como Évora e Porto.

D esde o século XV em Portugal há o registro da posse deum número exagerado de escravos pela nobreza como forma de conferir statuse prestígio (ibidem:96-7). M esmo entreuma nobreza menos abastada, era verificado o costume da utilização de escravos para gerarem renda (comercializando os produtos do trabalho dos cativos), chegando algumas casas a sobreviverem da riqueza produzida pelos escravos. 0 uso regular de escravos ("mouros" ou "negros") ganhando com seu trabal ho nas ruas o sustento de seus senhores era circunstância corriqueira em Portugal dos séculos XV e XVI. Tal prática era ainda mais visível e dinâmica nas cidades, como Lisboa, ondea possibilidade delucro dos senhores pela utilização de escravos era maior, quer pela utilização destes cativos como artesãos ou vendedores, quer alugando-os. ${ }^{15}$

D e fato, 0 ambiente urbano, diria Richard W ade (1964) em relação aos contextos urbanos escravistas do N ovo M undo, modificava em muito as relações detrabal ho, a utilização da mão-de-obra escrava ou a própria percepção da função dos escravos, e assim as formas de exercício do poder senhorial - formas de dominação que se empregavam no tratamento desses, demaneira geral. C omo salienta M ax W eber, a cidade oferece novas possibilidades de utilização dos escravos pelos senhores, redimensionando mesmo as formas como se estruturavam essas relações em todos os seus espectros (sociais, de trabal ho e produção, econômicas etc.). ${ }^{16}$ Estas são circunstâncias bem características de cidades-estado (Polis) do mundo antigo, mas que ocorre, aparentemente com bastante freqüência, nos usos da escravidão urbana moderna (W eber, 1983; W ade, 1964). N este sentido, estes contextos - de Lisboa dos séculos XV eXVI, G oa entre os séculosXVI eXVIII, do Rio entreos séculosXVIII eXIX (etalvez tantos outros) - podem ser percebidos como contextos escravocratas urbanos característicos da modernidade, inscritos numa lógica imperial. Compunham - cada qual diante das especificidades locai s e históricas correspondentes - paisagens humanas tão diversas quanto interativas, dando a estas cidadesmodernas (e "ocidentais" no sentido weberiano) um caráter cultural e sócio-demográfico cosmopolita - e porque não di- 
zer, gl obalizado? Afinal, estamos diante da convivência de grupos populacionais (esuas estruturas hierárquicas) desterritorial izados, quer fossem escravos africanos, colonizadores portugueses ou outrosgruposétnicosquecirculavam entreaspossessões deste "mundo português". U ma vez que estamos lidando com grandes cidades, com alto grau de concentração de populações desterritorial izadas produzidas por processos de migração (diáspora, em al guns casos), talvez pudéssemos recorrer ao conceito contemporâneo de "global ethnoscapes" (Appadurai, 1991) ${ }^{17}$ para ilustrar esta circunstância.

D esde o início do processo de expansão colonialista portuguesa, império e escravidão operaram quase como sinônimos. "D e fato, os nativos africanos tornaram-sefigura comum tanto na sociedade ocidental, quanto na oriental" (Pinto, 1992:50). D entro destalógica, como podemos pensar em fluxos depessoas sem pensar em fluxosdeformas depen samento (einstituições) destinadasa controlar/ordenar a vida destas pessoas?

Aliás este Estado português gl obalizado construiu uma especial excelência na transmigração de pessoas: quer do al to escalão diplomático, magistrados, da elite nobiliárquica (R ussel-W ood, 1993; Gonçalo Monteiro, 1998), quer de mão-de-obra menos qualificada (inclusive escravos), imprescindível à instalação efuncionamento da empresa colonial. Este éum império em constante fluxo e refluxo de pessoas, especialmente no caso da nobreza e da elite administrativa, que circulava entre as colônias ocupando cargos (burocráticos e de governo) (G onçalo M onteiro, 1998; BicaIho, 1997; Russell-W ood, 1993).

A colônia brasileira era apenas mais uma das possessões do ultramar português. N ão uma possessão desprezível, mas (ao menos até o período entre os séculos XVII e XV III) nem de longe a mais importante. Por ela circulavam oficiais, magistrados, administradores do staff da Coroa portuguesa que ocupavam cargos numa dinâmica que associava prestígios, honrarias e obtenção de recursosfinanceiros. 0 cupar um cargo de prestígio na administração das colônias do Brasil ou do G rão Pará eram honrarias intermediárias, em termos de importância, entre as colônias de África (um pouco abaixo), as do Estado da Índia (conjunto de possessões mai s importantes e valorizadas do ultramar português até o século XVIII, pelo menos), ou as da própria M etrópole portuguesa, que significavam o topo da carreira de diplomatas e administradores coloniais (R ussell-W ood, 1993). 
Em grande medida, as colônias operavam como "bases de experimentação" de políticas e procedimentosadministrativos das metrópoles que posteriormenteeram aplicados em outras colônias ou mesmo na administração das próprias metrópoles, no controle "doméstico" de populações (Souza Lima, 2002:155; Alencastro, 2000; Cohn, 1996: 3-15; Stolcke, 2001:3). Como bem lembra Elliot (1987:7) a experiência da colonização é fundamental mente uma experiência de confrontospopulacionais. Esta dimensão se torna mais dramática quan do lidamos com a idéia de escravidão e do conflito $^{18}$ enquanto um el emento inerente e estruturante destas sociedades escravistas coloniais modernas.

D esta forma, a instalação de uma empresa administrativa colonial ordenando a exploração do território brasileiro pela M etrópole portuguesa pressupunha também o acúmulo de experiências colonizadoras em outras localidades. A experiência anterior do aparelho administrativo português no arquipélago da M adeira e, mais tarde, em São Tomé - ambos antes de 1500 - funciona no sentido deum primeiro grandeempreendimento tropical colonizador. Experiência que será capital izada ao longo do século XVII com o empreendimento da introdução da lavoura canavieira no Brasil (Alencastro, 2000:63-70). Em outro sentido, a experiência urbana da gestão de um variado gradiente de formas de cati vidade em L i sboa e G oa também parecem ter sido características desta circunstância e se prestado ao mesmo expediente de acúmulo de experiências, que se traduziam mais objetivamente em conhecimentos sobre o "governo do bom cativeiro".

Partindo desta perspectiva, como frisou Verena Stolke (s/d:2) a colonização dal beroamerica esteve diante da imensatarefa de administração de "diversidades" (sociais, políticas e culturais). N a mesma démarche Souza Lima (2002:155) - estando especialmente atento ao governo de povos indígenas - ressal ta o fato de que é necessário observar-se como foram pensadas as "tradições de conhecimento para a gestão da desigual dade", em larga medida desenvolvidas por este aparel ho administrativo do ultramar português diante destas variadas experiências de colonização. ${ }^{19} \mathrm{~N}$ o processo de administração destas populações (autóctones ou transladadas), geraram-se inúmeros aparatosinstitucionais, cargosadministrativos, corpos de funcionários, códigos de leis, além deposturas corporais, códigos de etiqueta etc., destinados especificamente ao governo de determinados grupos populacionais. Como parte deste processo - faces diferentes de uma mesma moeda - , pari passu ao desenvolvimento deste aparato administrativo, inventa- 
ram-se comunidades. Como chamam a atenção Pagden (1987) e Souza Lima (2002) - a partir da leitura de Benedict Anderson (1983) - estamos lidando aqui com um processo de invenção de comunidades imaginadas: "comunidades que não existiam enquanto realidades percebidas, mas com parteda imaginação cultural ou política dos indivíduos, [...]" (Pagden: 1987:271).

U ma maneira de exemplificar isto de que se está falando é pensarmos numa das dimensões que envolvem o processo de criação destas comunidades imaginadas. Em seu fluxo de estabelecimento de redes de fornecimento de escravos em África, com a construção defeitorias, o desenvolvimento dealianças com al guns povoseguerras com outros ao longo devários séculos eem diversas regiões do continente, os portugueses lidaram com uma quantidade e variedade de etnias, grupos tribais e origens diferenciadas de africanos. N esta dinâmica e como parte deste fluxo de "administração de diversidades", os colonizadores acabaram criando uma série de formas diferenciadas, segundo a região e o período, para classificar os africanos que eram transladados entre as colônias. Como lembra Stolcke (2001:3), do contato entre colonizadores europeus, populações indígenas e escravos africanos surge um imenso gradiente de categorias sociais classificatórias. Classificar também é governar (diria Pierre Bourdieu, 1989). 0 desenvolvimento de formas de discriminação (e classificação) construiu maneiras particulares de racionalizar a dominação política (Stolcke, 2001:7).

A partir eem função da circulação e incorporação de grupos populacionais dentro da estrutura do ultramar português também protagonizou-se a inven ção de comunidades: "mouros", "gentios", "degredados", "órfãos" etc. Penso que podemos considerar os "escravos" etratar a idéia de "escravidão" sob esta mesma perspectiva. 0 corre que o termo e as práticas da escravidão assumiram utilizações distintas dentro da miríade de contextos que formavam o ultramar português (em tempos e terras diferentes).

Vivências de distintas e variadas formas de cativeiro eram conhecidas em vários contextos pré-colonizatórios e colonizatórios europeus, quer no N ovo M undo, quer na África, ou Ásia. Clarence-Smith (1987:3) sinaliza para este ponto em relação a sociedades da África oriental subsaariana, dizendo queal guns "escravos, com o passar do tempo, eram absorvidosnas categorias sociais de servos, sujeitos, parentes de uma mesma geração ou da seguinte". 0 utros autores apontam para o fato de que havia também, na Í ndia (não goêsa), um amplo gradiente de formas de servidão reco- 
nhecidas e praticadas localmente, mas classificadas sob a categoria escravidão. C omo diz D harma Kumar (1993), "o termo escravo, não descreve pormenorizadamente as muitas formas tradicionais de servidão [bondage] da Índia pré-colonial [que iam] desde a escravidão clássica até servidão por dívida [from chattel slavery to debt-peonage]". Indrani C hatterjee (1999:4-5) também estudando as formas de "escravidão" na India (não goesa), aponta para 0 fato de que a coexistência das formas escravas e livres (enquanto formas de trabal ho e de relação social), podem ter influenciando e modificado fortementeformas deconvívio social "não-escravas".

U m exercício interessante e produtivo é considerar o termo "escravidão" neste mesmo sentido, afinal, como aponta J ohannes Fabian (1986), a língua tem um papel fundamental no exercício do poder em circunstâncias coloniais. A penas como exemplo, tomando um dicionário português-konkane (língua nativa da região deG oa) desinônimos demeados do século XIX (Xavier, 1868) vemos que esse sinaliza nove diferentes significados para a palavra portuguesa servo (e dois para serva); três para escravo (outras três para escrava). M esmo sem entrarmos na análise pormenorizada destas categorias, a percepção desta variabilidade classificatória é uma dimensão muito significativa. Afinal, quantas formas diferentes de vivência da escravidão e de liberdade este o governo de territórios e populações haveria criado e/ ou subsumido?

D esnaturalizar, portanto, o significado de categorias (e mesmo idiomas) pode ser um caminho bastanteútil mesmo se - aliás, ainda mais se - estamos lidand o com uma sociedade que "fala" o mesmo idioma do observador, já que equívocos de utilização descontextual izada de catego rias sociais de classificação pela historiografia são muito corriqueiros. ${ }^{20}$ Por outro lado, a percepção dos usos sociais "nativos" destas categorias po de esclarecer bastante sobre as formas diferenciadas de administração de populações com as quais os colonizadores tiveram contato - tanto em sua gênese como na dinâmica de flutuação dos significados destas categorias - , como também sobre o próprio funcionamento cotidiano da sociedade. ${ }^{21} 0$ exercício de análise das categorias classificatórias utilizadas paraindexar os indi víduossubmetidosa um variado gradiente de formas de exploração de escravos negros africanos, populações autóctones submetidas a diferentes formas de servidão etc., pode se prestar a duas circunstâncias: a) tanto a de se perceber esta dinâmica de construção e sucessi vas transformações das categorias sociais como mais um elemento concorrente na lógica de administração de sociedades (e populações) coloniais; como, b) 
para retomar a perspectiva analítica enunciada mais acima neste texto, que oferece uma oportunidade de se realizar uma sociol ogi zação do campo intelectual a partir do confronto entre as apreensões dos significados das categorias nativas pelos nativos, em contraste com as re-significações das mesmas categorias pelo campo intel ectual. 0 u seja, esta arena de embates na qual podemoslocalizar as categorias pode ser analiticamente percebida em duas dimensões: uma que se refere à dinâmica de relações e mudanças a partir das diferentes apreensões feitas pelos "nativos", e outra de perceber o quanto o campo intelectual realiza um processo de imposição simbólica (Bourdieu: 1989) de significantes e significados aos usos sociais de categorias dos nativos.

Como exemplo disto, e retomando o contraponto comparativo indiano, segundo C hatterjee(1999), no contexto daquela historiografia dos séculos XIX eXX, os historiadores foram decisivos num processo deconstruir o estudo da escravidão como não legítimo do campo historiográfico. ${ }^{22}$ Por outro lado, incorriam em outro erro. Em grande medida, acolhiam as categorias de classificação das diferentes formas de trabalho (e dominação), desenvolvidas nos embates da burocracia administrativa colonial britânica do século XIX, incorporando-as ao discurso historiográfico acadê mico sem maiores reflexões teóricas. $D$ entro desta démarche, durante muito tempo a noção de "escravidão doméstica" foi tratada pela historiografia indiana como sinônimo de improdutiva (que não gerava capital, nem produtos concretos). 0 corre que a noção de escravidão doméstica não estava associada diretamente à noção daquelas ocupações realizadas exclusivamente no interior das residências senhoriais e ao funcionamento interno destas. Estava sim muito mais ligada àquelas atividades que procuravam garantir o sustento da família dos proprietários. Assim, a associação da idéia de escravi dão doméstica ao trabalho improdutivo obscurece uma sé rie deformas de trabalho escravo, por exemplo feminino einfantil (C hatterjee, 1999:3-5 e 1999b).

M esmo no caso da escravidão em Portugal, entre os séculos XV e XVI, como decorrência do processo de expansão marítima portuguesa e do contato com grupos étnicos diferenciados, foram surgindo categorias classificatórias, especialmente no trato com grupos populacionais africanos. "M ouro" e "gentio" foram al gumas destas. M ouro em verdadejá era uma categorialargamenteutilizada na classificação de grupos étnicos islamizados que foram sendo submetidos ao cativeiro durante o processo de expulsão da Península I bérica e de conquista do norte da África pelos portu- 
gueses (Bouchon, 1999:23-76). 0 termo "mouro" que designava em última instância cativo, foi paulatinamente caindo em desuso, dando lugar ao termo "escravo". I nteressante perceber neste contexto de Portugal continental do início do processo de expansão marítima, os dilemasquea entrada substantiva denegrosafricanos causaram nos sistemas classificatórios e de ordenação hierárquica de indivíduos e identidades sociais do Antigo Regime. D urante parte deste período mouro e escravo aparecem como sinônimos na legislação portuguesa. É só com as O rdenações M anuelinas (1514) que se notam diferenciações entre os termos (sendo mouro mais usado como sinônimo de "muçulmano"), acompanhando as mudanças na composi ção étnica da população cativa em Portugal. Como ressalta Saunders (1994:158), embora o termo escravo tenha aparecido, como um sinônimo, em substituição a mouro em Portugal no início da E ra M oderna, o tipo de relação de trabalho e cativeiro que o primeiro termo pressupunha não era homólogo ao segundo.

O historiador Sanjay Subrahmaniam (1997) chama a atenção para o fato de que a Era M oderna - mais especificamente aquilo que ele chama de "early modernity", que iria de meados do século XIV a meados do XV III - ébastantemarcada pel o aparecimento de conceitos universais e universalistas. C onceitos cunhados com o tom etnocêntrico europeu moderno e que, al ém de esmagar as diversidades locais/regionais (de crenças, conceitos e mesmo dossignificados contextuais de categorias), acabam servindo ao expediente do controle e domínio de populações.

Portanto, a percepção da existência de diferentes formas de vivência das relações de dominação - sob a rubrica da escravi dão - neste "mundo português", não deveria nos demandar o desenvolvimento de conceitosteóricos mais amplos e refinados, que englobassem esta diversidade?

U ma proposta interessante me parece a de consi derar o conceito de "catividade" - como pensou M arc Piault (1975) - como uma perspectiva mais ampla de conceituar a escravidão a partir de diferentes formas de servidão e dominação em África. Catividade, no sentido que se preten de recuperar, não estáligada apenasà idéia de pertencimento jurídico que a escravidão moderna pressupõe, mas a uma variedade de expedientes de dominação e exercício do poder. 0 utrossim, recuperar a idéia weberiana de dominação (suas formas e a sociologia), parece-me extremamente pertinente já que além do conceito ter serevelado bastanteútil para pensar asformas de governo da mão-de-obra escrava, vemos que grande parte das 
formulações daquele autor para a idéia de dominação foram desenvolvidas a partir do contraponto com o I mpério Romano. Em grandemedida, osimpérios colonial istas europeus do período moderno constroem a própria idéia de império a partir dos impérios clássicos, especialmente o romano. ${ }^{24}$ Anthony Pagden (1987; 1995) ressalta o quanto essa característica não é apenas um mero detalhe, masum ponto fundamental quando se está pensando nas formas burocráticas de administração destes impérios coloniais da Era M oderna. N este sentido me parecelegítimo, além deste trabaIho de esmiuçar o léxico português do exercício do poder edaspráticas de dominação do ultramar português, também tentar buscar a sócio-gênese das idéias de governo de populações usadas neste contexto, fora dele, tanto na própria Era M oderna, quanto no Império Romano.

\section{Inventando a G lobalização}

M uitas das teorias sociológi cas que discutem as idéias de gl obalização caracterizam este como um processo marcado por interação comparativa de diferentes formas de vida, com um contato, às vezes traumático (Robertson, 1992:27) ou processos de transmigração e reordenamento de estrutura social. L evando em conta estas características de governo de populações levadas adiante pelo império português, poderíamos concordar que globalização, fluxo de bens, capitais, pessoas e costumes correspondem a um processo contemporâneo recente? 0 que é real mente novo, imprecedentee original neste processo de gl obalização quenão vem ocorrendo, em larga escala, desde o princípio dos tempos modernos? N ão estaríamos diante de uma excessi va valorização de uma agen da do campo intelectual que não é assim tão nova? Afinal é este um processo tão recente na história da humanidade, como dizem alguns autores (ibidem; Appadurai, 1991)?

Certamente, muito do que o campo intelectual chama de globalização está associado a movimentos característicos da M odernidade, como processos de civilização (Elias, 1990). Por processo de civilização não se quer dizer ocidental ização. C omo nos parece, a relação entre colônias e metrópole(s) é permeada pelo signo da intensa dinâmica, tanto no fluxo e refluxo de coisas e pessoas, quanto de formas de pensamento, envolvendo ambos os pólos.

Além de recuperar na história da colonização de $G$ oa e do Rio de Janeiro, a partir de pontos concretos de contato (rotas co- 
merciais, a circulação de indivíduos, correspondências entreautoridades administrativas etc.), parece interessante tentar reconectar estes pontos desde as políticas administrativas do império ultramarino português quanto às experiências de gestão de grupos populacionais largamente utilizados como escravos. É certo, porém, que estas políticasnão foram desenvolvidas em um único contexto e aplicadas em vários outros. Eram produto de constantes mudanças e adequações a conjunturas específicas (sociais e históricas) de cada sítio (e mesmo readequações dentro de cada sítio). Ademais, 0 fato de 0 aparelho administrativo colonial português (tanto quanto outrosaparel hoscoloniais) se servir do expediente de experimentar formas de governo em um contexto colonial, para posteriormente aplicá-lo em outro (ou na própria metrópole), não faz com que o tipo de escravidão urbana carioca seja um produto direto, uma conseqüência, das formas de administração da escravidão em G oa, em Lisboa, ou em qualquer outra colônia (ou possessão) portuguesa. G oa e Rio de J aneiro não são, com toda certeza, universoshomólogos em rel ação às condições eformas de vida escrava urbana. Entretanto, ambos contam com uma di versidade expressiva de formas de dominação. ${ }^{25}$

Se tomarmos as ligações "concretas" (de carne e osso) entre Rio de Janeiro e $G$ oa iremos verificar que, ainda que existissem (veja-se Anthony, 1990; Pinto, 1990; Shastry, 1990), eram muito tênues as relações entre estas duas possessões. Por outro lado, e como formula de maneira interessante Sanjay Subrahmaniam (1997), podemos tomar as ligações entre estes dois pontos a partir da noção de H istórias C onectadas (conectávei s para ser mais preciso). Se por um lado ligações "concretas" entre Rio de Janeiro e G oa, a partir da relação entre estas duas localidades são muito tênues, por outro lado, podemos nos servir das próprias políticas do Estado ultramarino português para comparar diferenças de percepção e aplicação de diretrizes imperiais no exercício da gestão da escravidão. N este sentido, como bem marcou Jeanette Pinto (1992), durante o período de expansão imperialista portuguêsimpério e escravidão operavam quase como sinônimos; é importante acrescentar que escravidão e negros africanos não eram, originalmente, sinônimos. E mais, que numa estrutura social baseada no trabal ho escravo, muitas formas de trabal ho acabavam tendo esta como uma referência fundamental (um horizonte) na ordenação das relações entre dominante e dominado, quer fossem el es patrão e empregado, senhor e servo etc. 
Pensadas de maneira mais ampla, estas políticas desenvolveram léxicos relacionados ao exercício do poder que serviram também no expediente de criar estes grupos sociais (como os escravos, por exemplo), além de políticas específicas para seu tratamento, como partes integrantes deste processo de construção de conhecimentos e práti cas de governo destas diversi dadese da gestão destas desi gual dades. $O$ utra conseqüência disto foi a formação degrupos populacionais historicamentealijados do processo de participação no mainstream da sociedade. A observação deste processo também nos mostra muito sobre circunstâncias históricas específicas na criação de identidades de exclusão sociais para determinados grupos populacionais específicos.

\section{NOTAS}

1. U ma versão modificada deste texto foi publicada em Sundaram \& K ay Jin, G lobalization and its D iscontents, Revisited (2003). Agradeço aos editores as observações, bem como a gentileza de liberarem o texto para a presente publicação.

2. O presentetexto faz partede umainvestigação em curso, integrando as discussões de minha tese de doutoramento. Sendo assim apresenta, em al guns momentos, um caráter exploratório ede colocação dequestões, mais do que o estabelecimento de conclusões finais. Agradeço as sugestões eindicações deleituras deinúmeras pessoas, entre elas dos Profs. Antonio C. Souza Lima (PPGAS/U FRJ), Sanjay Subramaniam (EHESS), T etsuo M aruyama (Bukkyo University, K yoto) e John M onteiro (U nicamp).

3. Iniciamos nossa reflexão pela cidade do R io de J aneiro por ser o pólo da pesquisa no qual foram feitas investigações empíricas mais aprofundadas e, por conseguinte, sobre o qual se detém maior acúmulo de informações.

4. Apenas a título de comparação, em 1800, quando da transferência da capital dos USA da Filadélfia para W ashington, o staff administrativo governamental girava em torno demil pessoas (incluindo desde o presidente até os cocheiros do serviço postal) (Alencastro, 1997:12). Já a famosa corte francesa de Luís XIV contava com dez mil integrantes (entre nobres e o staff de cortesãos e criados) (Elias, 1995).

5. A "escravidão doméstica" (Burlamaque, 1837) era classificada por al guns autores brasileiros do século XIX como uso dos escravos para as necessidades do proprietário, 0 queW eber (1983:1026) chamou de "uso consumptivo" dos escravosurbanos da Antigüidade.

6. Trabalhar "ao ganho" é uma expressão de época que designava os escravos que, em ofícios variados (desde carregadores até al faiates), trabal havam por uma empreitada ou período detempo determinados, para uma pessoa quenão era seu proprietário.

7. Silvia Lara (2000) faz uma enorme compilação, eanálise, detoda (ou quase) a legislação produzida pelo império ultramarino português para a administração de populações escravas negras em suas possessões. 
8. Como chama a atenção Souza Lima(2003:154): “Asformas políticas, as tradições de conhecimento geradas na metrópole e redefinidas através do encontro e da experiência colonial, efeito de um processo de mútua constituição, num mundo que hoje é cada vez mais pensado a partir de noções como as de fluxos, redes e processos, têm permanecido de fora de uma pesquisa aprofundada. E nisso pode-se incluir muito das Ciências Sociais".

9. “D esde o final do século XVI, surgem um espaço aterritorial, um arquipélago lusófono composto dos enclaves da A mérica portuguesa e das feitorias deAngola. É daí que surge o Brasil no século XVIII. [...] essas duas partes unidas pel o oceano se completam num só sistema de exploração colonial cuja singularidade ainda marca profundamente o Brasil contemporâneo". (Alencastro, 2000:9).

10. Este aspecto também é enfatizado por Saunders (1992:100-1) a respeito do uso de escravos e servos em Portugal continental. D eresto pareceter constituído uma espécie de característica que acompanha a utilização de escravos no Brasil, colônia e ex-colônia.

11. Ver Rego (1947, v. I:143). Jeanette Pinto (1992:66) também assinala sobre uma documentação de meados do século XVI (1569) que registra o batismo de 248 escravos de portugueses na Í ndia, dentre os quais figuravam 12 brâmanes.

12. M esmo 0 aparel ho administrativo desteEstado ultramarino português recorria à utilização de escravos negros africanos (na forma de marinheiros ou soldados, por exemplo).

13. M esmo nas cidades da Antigüidade esta situação ocorria, dizia Max Weber (1983:1026): "toda acumulação de fortunas, significava uma acumulação de possessão de escravos".

14. É interessante notar que há medidas tomadas diretamente pela coroa portuguesa (desde o século XVI), no sentido de coibir o uso excessivo de violência e castigos na regulação da relação entre senhores e escravos.

15. Portugal dos séculosXV eXVI apresentava, ao que sugere Saunders (1994:115 e ss.) um quadro bastante rico do ponto de vista das diferentes formas do exercício do poder e do emprego da mão-de-obra cativa. "Escravos", "livres", "mouros", "brancos", "mulatos", "negros" e "indianos" disputavam mercado de trabal ho nas ruas das cidades (como Lisboa, que já contava com 100 mil habitantes em meados dos quinhentos).

16. “A circunstância de que a cidade era um mercado que oferecia ocasião rel ativamente constantepara ganhar dinhei ro pel o comércio ou pelo artesanato, induzia muitossenhores a utilizar seus escravos e servos como 'fonte derendas' em lugar de como 'for ça detrabal ho' na própria casa ou explorando-os, assim que os ensinavam como artesãos ecomerciantes e logo até os dotavam em ocasiões (assim na Antigüidade) com meios de exploração para que, em troca do pagamento de um valor, fossem para as cidades para ganhar sua vida. N as construções públicas de A tenas en contramos livres eescravosparticipando de uma mesma tarefa coletiva de salários." (W eber, 1983:957, ênfase minha).

17. Appadurai (1991) desenvolve, em um artigo breve, a idéia de que, em função do fenômeno recente da desterritorialização, da migração de contingentes populacionais de uns países para outros, formariam "paisagens étnicas globais". A partir desta no- 
ção, debruça-se sobrea análise do papel da "imaginação" nas trajetórias de vida destas pessoas.

18. Pressuponho aqui a idéia de conflito tal como formulada pelo sociólogo alemão G eorg Simmel (1964).

19. E, nesta lógica, escravos negros africanos eram apenas um entre os demais grupos (contingentes) populacionais com os quais os colonizadores portugueses lidavam e em relação aos quais geravam conhecimentos de administração populacional.

20. “Anál ises históricas correm o risco deanacronismo quando aplicam significados culturais do presente ao passado. U ma exploração historicamente contextualizada das categorias classificatórias que foram implantadas pela sociedade colonial ibérica e seus precedentes metropolitanos é tudo menos trivial." (Stolcke, 2001:7).

21. Como ressalta Stolcke(2001:7): “Estas categorias ideológicas de discriminação social desempenharam um papel fundamental na organização elegitimação da espoliação e opressão de populações indígenas como também de escravos africanos e seus descendentes mestiços, através disso constrangendo severamente suas possi bilidades deascensão social e/ ou negando-Ihes sua dignidade humana deformas particulares".

22. "A obstrução de uma instituição largamente difundida, provavelmente não foi, em nenhum outro lugar, tão completa, como na escrita da H istória do sudeste da Ásia, onde a escravidão foi desalojada das narrativas de poder e da construção do Estado em direção aos interstícios da história social e econômica" [...] (1999:1).

23. U ma reflexão semelhante pode ser encontrada para a idéia de trabal ho doméstico no hinterland de Lisboa entre meados do século XVIII e princípios do XIX (Silva, 1987).

24. H avia mesmo uma leitura intensa de clássi cos greco-romanos sobre processos de civilização ligados à discussão de agronomia, por exemplo. A própria idéia de império, aliás, estava também presente em várias sociedades fora do mundo europeu moderno, como ressal ta Subrahmaniam (1997) em impérios do sudesteasiático, África ealguns pontos da A méricas.

25. Como aponta Fredrik Barth (1995:7) “diferença e diversidade, podem ser conceitualmente transformadas em um campo de variabilidade, levando progressivamente à construção de um conjunto de dimensões de variação para facilitar minha descrição de qualquer forma que eu tenha observado. U m conjunto de descrições nos termos destas dimensões, por outro lado, abre espaço para analisar como certas características tendem a co-variação, ou seja, podem ser interdependentes e interconectadas".

\section{Referências Bibliográficas}

ALEN CAST RO , L.F. (1997). "Vida Privada e O rdem Privada no I mpério". In: H istória da vida privada no Brasil. São Paulo, Companhia das Letras, pp. 11-93.

. (2000). O T rato dos Viventes. São Paulo, Companhia das Letras.

ALM EID A, R. H . (1997). 0 diretório dos Índios. Brasília, U nB.

AN DERSO N , B. (1983). Imagined Communities. London, Verso.

AN TH ONY, P. (1990). "C olonial Brazil and G oa: V isibleand InvisibleLinks". Purabhilekh-Puratatva (J ournal of the D irectorate of Archives, Archaeology and M useum), 8 (1), pp. 71-85. Panaji (Goa). 
APPAD U RAI, Arjun (1991). “G lobal Ethnoscapes: N otes and Q ueriesfor aTransnational Anthropology". In: R. Fox, Recapturing Anthropology. Working in the Present. Santa Fe, School of American Research Press, pp. 191-210.

BARTH , F. (1995). Comparative M ethodologies in the Analysis of Anthropological $D$ ata. C onferência ministrada na $W$ ashington U niversity, 10 de setembro.

BICALH O, M . F. B. (2003). A Cidade e I mpério: O Rio de janei ro no Século XVIII. Rio de Janeiro, Civilização Brasileira.

BO U CH ON, G eneviève (1999). Inde D écouverte, Inde Retrouvée, 1498-1630. Études d'H i stoi re Indo-portugaise. Lisboa \& Paris, Calouste Gulbekian, C N PCD P.

BO U RDIEU , Pierre (1989). 0 Poder Simbólico. Rio de Janeiro/Lisboa, Bertrand/D ifel.

BOXER, C. R. (1982). A Índia Portuguesa em M eados do Século XVII. Lisboa, Ed. 70.

CHATTERJEE, Indrani (1999). Gender, Slavery and Law in Colonial India. Delhi, Oxford U niversity Press.

(1999b). "C olouring Subalternity: Slaves, Concubines and Social O rphans in Early Colonial India". Subaltern Studies, no 10, pp. 49-97. D elhi.

CLAREN CE-SM ITH , W. G . (1989). TheE conomics of the Indian 0 cean Slave Trade in the $N$ ineteenth Century. London, Frank C ass \& $\mathrm{C} 0$.

CROSBY, A. W. (1990). Ecological Imperialism: The Biological Expansion of Europe, 900-1900. Cambridge, Cambridge U niversity Press.

CURTI N , P. D . (1969). TheAtlantic SlaveT rade: A C ensus. M adison, $U$ niversity of W isconsin Press.

ELIAS, N . (1995). A Sociedade de C orte (2 ${ }^{\underline{a}}$ ed.). Lisboa, Editorial Estampa. (1990 [1939]). O Processo Civilizador. Rio de Janeiro, JZE.

ELLIOTT, J. H . (1987). "Introduction: C olonial I dentity in the Atlantic W orld". In: A. Pagden \& N . Canny (eds.), C olonial I dentityin the Atlantic W orld: 1500-1800. Princeton, Princeton U niversity Press.

FABIAN , J. (1986). Language and Colonial Power: The Appropriation of Swahili in the Former Belgian Congo, 1880-1938. Berkeley, U niversity of California Press.

FRAG O SO , J.L. (1992). H omensdeG rossa Aventura: A cumulação eH ierarquia na Praça M ercantil do Rio de Janeiro (1790-1830). Rio de Janeiro, Arquivo N acional.

FREYRE, G . (1940). O M undo que o Português Criou. Rio de Janeiro, José O lympio. (1954 [1933]). Casa Grande\& Senzala. Formação da Família Brasileira sob o Regi me de Economia Patriarcal. Rio de Janeiro, Livraria J osé O lympio Editora

GEN O VESE, E. D . (1983). Da Rebelião à Revolução. São Paulo, G lobal.

GO N ÇALO M O N T EIRO , N . (1998). 0 Crepúsculo dosG randes. Lisboa, I mprensa N acional da Casa da M oeda.

GROVE, R. (1996). Green Imperialism: Colonial Expansion, Tropical I sland Edens and the 0 rigins of Environmentalism, 1600-1800. Cambridge, C ambridge U niversity Press.

KARASC H , M . C. (1987). SlaveL ifein Rio deJaneiro, 1808-1850. Princeton, Princeton University Press.

LARA, S. H . (2000). “Legislação sobre Escravos Africanos na América Portuguesa”. In: J. Andrés-G allego (coord. ), N uevasA portacionesa la H istória J urídica del beroamérica. Madri, Fundación Histórica Tavera, Collección Proyetos Históricos Tavera (CD-Rom). 
(2002). "Linguagem, D omínio Senhorial el dentidade Étnica nas M inas G erais de M eados do Século XVIII". In: C. Bastos; M. V. deAlmeida \& B. Feldman-Bianco, Trânsitos Coloniai s: D iálogos C ríticos L uso-Brasileiros. Lisboa, ICS, pp. 205-225.

M ALERBA, J. (2000). A Corte no Exílio. São Paulo, Companhia das Letras.

M ATT OS, H ebe M . (2001). "A Escravidão M oderna nos Q uadros do Império Português: 0 Antigo Regimeem PerspectivaAtlântica". In: M. F. Bical ho et alli (orgs.), 0 Antigo RegimenosT rópicos: A D inâmica Imperial Portuguesa. Rio de Janeiro, Civilização Brasileira, pp. 141-162.

M O N TEIRO, John. (1988). "From Indian to Slave: Forced N ative Labour and Colonial Society in São Paulo during the Seventeenth Century". Slavery \& Abolition, 9 (2), pp. 105-127.

PAGDEN, A. \& CANNY, N. (1987). Colonial Identity in the Atlantic World: 1500-1800. Princeton, Princeton U niv. Press.

_ (1995). Lords of All the W orld. London and N ew H aven, Yale U niversity Press.

PERDIGÃO M ALH EIRO , A. (1976 [1866-67]). A Escravidãono Brasil: Ensaio H istóriCo, Jurídico, Social. Petrópolis, Ed. Vozes, 2 v.

PIAU LT , M . H . (1975). "C aptifs du Pouvoir et Pouvoir des C aptifs". In: C. M eillassoux, L'Esclavage em Afrique Précoloniale. Paris, M aspero, pp. 321-350.

PIN H EIRO , C . C. (1998). Q uereis Ser Escravo? Escravidão, Saberes de D ominação e Trajetórias deVidanaC idade do R io deJ aneiro, 1808-1865. D issertação demestrado, Rio de Janeiro, UFRJ.

PIN T O , C. (1990). "At the D usk of Second Empire: Goa-Brazil Commercial Links, 1770-1826". Purabhilekh-Puratatva (J ournal of the D irectorate of Archives, Archaeology and M useum), vol. 8, no 1, pp. 41-69. Panaji (G oa).

PIN T O , J. (1992). Slavery in Portuguese India, 1540-1842. Bombay, H imalaya Publishers.

REGO , A. da S. (1947). D ocumentação para a H istória das M issões do Padroado.

REIS, João J . (1987). R ebelião Escrava no Brasil. A H istória do Levante dos M alês (1835). São Paulo, Brasiliense.

ROBERTSO N, R. (1992). Globalization. Social Theory and Global Culture. London, Sage.

RU SSELL-W O O D , A. J. R.. (1993). A W orld on theM ove. N ew York, St. M artin'sPress. SALA M O LIN S, L. (1992). L'Afriqueaux Ameriques: LeC odeN oir Espagnol. Paris, PU F.

SAUN DERS, A. C . deC . M . (1994 [1982]). H istória Social dosE scravoseL ibertosN egros em Portugal (1441-1555). Lisboa, Imprensa N acional/C asa da M oeda.

SH AST RY, B. S. (1990). "Goa and Brazil: Economic Ties (1700-1750)". Purabhilekh-Puratatva (J ournal of the D irectorate of Archives, Archaeology and M useum), vol. 8, no 1, pp. 87-93. Panaji, Goa.

SILVA, Álvaro F. (1987). "Família e Trabalho no H interland de Lisboa: O eiras, 1763-1810". Análise Social, 23(97), pp. 531-562. Lisboa.

SI M M EL, G. (1964 [1908]). "C onflict". Conflict and the web of group-affiliations. N ew York, The Free Press, pp. 11-123.

SO U ZA LIM A, A. C. (2002). "Tradições de Conhecimento para a G estão C olonial da D esigual dade. Reflexões a partir da Administração Indigenista no Brasil”. In: C. 
Bastos; M . V. Almeida \& B. Bianco (coords.), T rânsitosColoniais: D iálogos Críticos Luso-Brasileiros. Lisboa, Imprensa de C iências Sociais, pp. 151-172.

ST O LCKE, V. (2001). "A N ew W orld Engendered. The Building of the Transatlantic $\mathrm{H}$ ispanic and L uso-american Empires between theXVI and theXIX C enturies". Paper apresentado no D epartamento de Antropologia, M useu N acional/U FRJ, 3 de setembro de 2001.

SU BRAH M AN IAM , S. (1997). "C onnected H istories: N otesTowards R Reconfiguration of Early M odern Eurasia". M odern Asian Studies, vol. 31, no 3, pp. 735-762.

SU N D ARAM , J. K. \& KAY JIN , K. (eds.) (2003). Globalization and itsD iscontents, Re visited. London/Amsterdam, Sephis/ZED.

W AD E, R. C. (1964). Slavery in the Cities: The South 1820-1860. London, O xford U niversity Press.

W EBER, M .. (1958). T he City. N ew York/London, The Free Press/C ollier-M acmillan Limited.

(1983). Economia y Sociedad. Ciudad de M éxico, Fondo de Cultura.

XAVIER, F. (1868). D iccionário Portuguez-C oncani, Composto por um M issionáriol taliano. N ova G oa, Imprensa N acional.

ZURARA, G . E. da(1994 [1453]). Crônica deG uiné. Lisboa, Livraria Civilização E ditora. 